International Journal of Current Microbiology and Applied Sciences

ISSN: 2319-7706 Volume 6 Number 8 (2017) pp. 2904-2908

Journal homepage: http://www.ijcmas.com

Original Research Article

https://doi.org/10.20546/ijcmas.2017.608.347

\title{
Influence of Organic and Inorganic Nutrients in Tomato (Solanum lycopersicum L.) For Nutrient Uptake and Yield under Shade Net Condition
}

\author{
S. Sridharan*, S. Mariappan and T. Arumugam \\ Department of Horticulture, Agricultural College and Research Institute, \\ Madurai, Tamil Nadu, India \\ *Corresponding author
}

\section{A B S T R A C T}

Keywords

Tomato hybrid,

Bio fertilizers,

Nutrient uptake.

Article Info

Accepted:

23 June 2017

Available Online:

10 August 2017
The present study was conducted to evaluate the effect of organic and inorganic nutrient application on nutrient uptake and fruit yield of hybrid tomato grown in a under shade net condition. $\mathrm{T}_{10}(50 \% \mathrm{~N}+\mathrm{P}+$ Azophosmet) and constant level of $200 \mathrm{~kg}$ of $\mathrm{K}_{2} \mathrm{O}$ is applied in the form of muriate of potash was found that highest uptake of $\mathrm{N}$ (162.59 and $\mathrm{N} 160.74$ $\left.\mathrm{Kg} \mathrm{ha}^{-1}\right), \mathrm{P}\left(21.96 \mathrm{Kg} \mathrm{ha}^{-1}\right.$ and $\left.21.14 \mathrm{Kg} \mathrm{ha}^{-1}\right)$ and $\mathrm{K}(156.40$ and $156.25 \mathrm{Kg}$ $\mathrm{ha}^{-1}$ ) during the first and second season crop, respectively. The uptake of nutrient by the tomato plants showed a gradual increase with the progressive growth and development of the crop. Among the treatment $\mathrm{T}_{10}$ $(50 \% \mathrm{~N}+50 \% \mathrm{P}$ and $100 \% \mathrm{~K}$ of RDF $+2 \mathrm{~kg}$ Azophosmet) recorded highest yield per hectare $\left(125.09 \mathrm{t} \mathrm{ha}^{-1}\right)$.

\section{Introduction}

Tomato (Solanum lycopersicum L.) is most important vegetable crop grown in the world. The fruit is a rich source of vitamin A (590 microgram / 100g), Ascorbic acid (27 $\mathrm{mg} / 100 \mathrm{~g}$ ) and lycopene. Integration of different organic sources and inorganic sources of plant nutrients exhibited an increase in yield and yield related attributes of tomato. This is possibly due to balanced $\mathrm{C}$ : $\mathrm{N}$ ratio, more decomposition, more mineralization, more availability of native and applied macro and micronutrients. All these might have accelerated the synthesis of carbohydrates and its better translocation from sink to source might have led to an improvement in yield and yield related attributes.

\section{Materials and Methods}

Tomato (Solanum lycopersicum) COTH 3 is a Semi determinate hybrid were used for the study. Twenty five day old seedlings were planted under fifty percent shade net condition. Treatment are imposed $\mathrm{T}_{1}(200 \mathrm{Kg}$ $\mathrm{N}+300 \mathrm{Kg} \mathrm{P}_{2} \mathrm{O}_{5}+200 \mathrm{Kg} \mathrm{K} 2 \mathrm{O}(\mathrm{RDF}), \mathrm{T}_{2}$ $(100 \% \mathrm{~N}+\mathrm{P}+$ Azophos $), \mathrm{T}_{3}(100 \% \mathrm{~N}+\mathrm{P}+$ Methylobacterium), $\mathrm{T}_{4}(100 \% \mathrm{~N}+\mathrm{P}+$ Azophosmet), $\mathrm{T}_{5}(75 \% \mathrm{~N}+\mathrm{P}+$ Azophos $), \mathrm{T}_{6}$ $(75 \% \mathrm{~N}+\mathrm{P}+$ Methylobacterium $), \mathrm{T}_{7}(75 \%$ $\mathrm{N}+\mathrm{P}+$ Azophosmet $), \mathrm{T}_{8}(50 \% \mathrm{~N}+\mathrm{P}+$ Azophos $), \quad \mathrm{T}_{9} \quad(50 \% \mathrm{~N}+\mathrm{P}+$ Methylobacterium), $\mathrm{T}_{10}(50 \% \mathrm{~N}+\mathrm{P}+$ Azophosmet). A constant level of $200 \mathrm{~kg}$ of $\mathrm{K}_{2} \mathrm{O}$ is applied in the form of muriate of potash for all treatments. The above treatments were given in first and second 
season crop. This study conducted at AC \& RI, Madurai, during first season crop (July 2012 to December 2012) and the second season crop (December 2012 to April 2013). The experimental was laid RBD with three replications.

\section{Results and Discussion}

The treatment $\mathrm{T}_{10}(50 \% \mathrm{~N}+50 \% \mathrm{P}$ and $100 \%$ $\mathrm{K}$ of RDF $+2 \mathrm{~kg}$ Azophosmet) was found that highest uptake of $\mathrm{N}(162.59$ and $\mathrm{N} 160.74 \mathrm{Kg}$ $\mathrm{ha}^{-1}$ ) during the first and second season crop. Among the two seasons the treatments Significant difference ware observed among the treatment $\mathrm{T}_{10}$ recorded the highest uptake of $\mathrm{P}\left(21.96 \mathrm{Kg} \mathrm{ha}^{-1}\right.$ and $\left.21.14 \mathrm{Kg} \mathrm{ha}^{-1}\right)$ in first and second crop respectively. Treatment $\mathrm{T}_{10}$ was recorded highest uptake of K 156.40 and 156.25 Kg ha ${ }^{-1}$ during the first and second season crop.

The uptake of nitrogen by the tomato plants showed a gradual increase with the progressive growth and development of the crop. This may be due to the increased $\mathrm{N}$ content in the plant tissues and increased dry matter production. A similar trend in $\mathrm{N}$ uptake was noticed by Dikkova et al., (1981), Nandhakumar and Veeraragavathatham (2003) in brinjal.

The application of inorganic fertilizers in combination with biofertilizers exihibited the higher $\mathrm{N}$ uptake. This is in agreement with the findings of Dhanalakshmi and Pappaiah (1993) in tomato. Biofertilizers can fix the atmospheric nitrogen. Hence, increasing the available $\mathrm{N}$ in the soil (Gaur, 1990) and this ultimately leads to increased $\mathrm{N}$ uptake of the plant.

The uptake of $\mathrm{P}$ due to biofertilizer inoculation can be might have production of enzymatic complex by phosphobacteria which solublize the unavailable phosphorus resulting them into forms easily available to roots. The increased absorbing root surface also might have resulted in higher nutrient uptake (Venkateshwarlu and Rao, 1983 and Rokade and Patil, 1993).

The uptake of potassium was positively influenced by higher level of nutrients. Positive effect of nitrogen application uptake of K was reported by Hammond et al., (1951) in soyabean. Biofertilizers also increased the $\mathrm{K}$ uptake in many crops. Similar increase in nutrient uptake also was reported in winter legumes compared to control.

The better root growth due to Azospirillum and Phophobacteria might have triggered the mechanism of higher uptake of K. Increased uptake of NPK due to Azospirillum and Phophobacteria was reported in Pumpkin (Karuthamani, 1995).

The treatment had significantly influenced the individual fruit weight in tomato fruit in two seasons. Among the two seasons significant differences were observed among the treatment $\mathrm{T}_{10}(50 \% \mathrm{~N}+50 \% \mathrm{P}+100 \% \mathrm{~K}$ of $\mathrm{RDF}+2 \mathrm{~kg}$ Azophosmet) recorded the highest fruit weight $(65.16 \mathrm{~g}$ and $65.20 \mathrm{~g}$ ) in first and second crop respectively, In both the seasons, the treatments $\mathrm{T}_{10}(50 \% \mathrm{~N}+50 \% \mathrm{P}$ $+100 \% \mathrm{~K}$ of RDF $+2 \mathrm{~kg}$ Azophosmet) had the highest fruit weight $(65.18 \mathrm{~g})$ and the treatment $\mathrm{T}_{1}$ (control) recorded the lowest fruit weight $(52.59 \mathrm{~g})$ also treatments were highly significant in first and second season crop respectively.

Among the treatment $\mathrm{T}_{10}(50 \% \mathrm{~N}+50 \% \mathrm{P}$ and $100 \% \mathrm{~K}$ of RDF $+2 \mathrm{~kg}$ Azophosmet) recorded highest yield per hectare $(125.09 \mathrm{t}$ $\left.\mathrm{ha}^{-1}\right)$ followed by $\mathrm{T}_{8}(50 \% \mathrm{~N}+50 \% \mathrm{P}$ and $100 \% \mathrm{~K}$ of $\mathrm{RDF}+4 \mathrm{~kg}$ Azophos) which recorded $124.26 \mathrm{t} \mathrm{ha}^{-1}$ but the treatment $\mathrm{T}_{1}$ (control) registered the less yield per hectare $\left(97.89 \mathrm{t} \mathrm{ha}^{-1}\right)$. In the second crop significant difference were observed (Tables 1 and 2). 
Table.1 Influence of Nutrient Uptake of Nitrogen $\left(\mathrm{Kg} \mathrm{ha}^{-1}\right)$, Phosphorus $\left(\mathrm{Kg} \mathrm{ha}^{-1}\right)$ and Potassium $\left(\mathrm{Kg}^{-1}\right)$ of Tomato (COTH 3) Under Shade Net Condition Using graded dose of N, P and biofertilizers grown in two seasons

\begin{tabular}{|c|c|c|c|c|c|c|c|c|c|}
\hline \multirow[b]{2}{*}{ Treatments } & \multicolumn{3}{|c|}{ Uptake of $\mathbf{N}$} & \multicolumn{3}{|c|}{ Uptake of $P$} & \multicolumn{3}{|c|}{ Uptake of $K$} \\
\hline & $\begin{array}{c}1^{\text {st }} \text { season } \\
\text { crop }\end{array}$ & $\begin{array}{c}2^{\text {nd }} \text { season } \\
\text { crop }\end{array}$ & $\begin{array}{c}\text { Pooled } \\
\text { mean }\end{array}$ & $\begin{array}{c}1^{\text {st }} \text { season } \\
\text { crop }\end{array}$ & $\begin{array}{c}2^{\text {nd }} \text { season } \\
\text { crop }\end{array}$ & $\begin{array}{c}\text { Pooled } \\
\text { mean }\end{array}$ & $\begin{array}{c}1^{\text {st }} \text { season } \\
\text { crop }\end{array}$ & $\begin{array}{c}2^{\text {nd }} \text { season } \\
\text { crop }\end{array}$ & $\begin{array}{c}\text { Pooled } \\
\text { mean }\end{array}$ \\
\hline $\mathrm{T}_{1}$ & 123.70 & 125.55 & 124.62 & 17.33 & 16.77 & 17.05 & 137.96 & 138.07 & 138.01 \\
\hline $\mathrm{T}_{2}$ & 145.55 & 146.66 & 146.10 & 19.96 & 19.37 & 19.66 & 149.96 & 148.88 & 149.42 \\
\hline $\mathrm{T}_{3}$ & 143.70 & 141.48 & 142.59 & 19.51 & 18.62 & 19.06 & 148.81 & 140.03 & 144.42 \\
\hline $\mathrm{T}_{4}$ & 152.22 & 151.85 & 152.03 & 20.51 & 19.99 & 20.25 & 154.70 & 154.59 & 154.64 \\
\hline $\mathrm{T}_{5}$ & 129.25 & 127.40 & 128.32 & 18.40 & 17.88 & 18.14 & 140.59 & 143.33 & 141.96 \\
\hline $\mathrm{T}_{6}$ & 134.81 & 133.70 & 134.25 & 18.85 & 17.40 & 18.125 & 139.99 & 149.70 & 144.84 \\
\hline $\mathrm{T}_{7}$ & 139.99 & 140.37 & 140.18 & 18.11 & 18.48 & 18.29 & 153.55 & 153.59 & 153.57 \\
\hline $\mathrm{T}_{8}$ & 157.77 & 156.29 & 157.03 & 20.99 & 20.59 & 20.79 & 155.14 & 154.88 & 155.01 \\
\hline $\mathrm{T}_{9}$ & 148.88 & 150.74 & 149.81 & 17.66 & 17.59 & 17.62 & 152.85 & 152.70 & 152.77 \\
\hline $\mathrm{T}_{10}$ & 162.59 & 160.74 & 161.66 & 21.96 & 21.14 & 21.55 & 156.40 & 156.25 & 156.32 \\
\hline SE.d & 0.2007 & 0.1951 & 0.1975 & 0.0249 & $\mathbf{0 . 0 2 3 7}$ & 0.0240 & 0.1136 & 0.1068 & 0.1040 \\
\hline$C D(p=0.05)$ & 0.4216 & 0.4098 & 0.4149 & 0.0522 & 0.0498 & 0.0504 & 0.2386 & 0.2245 & 0.2186 \\
\hline
\end{tabular}

Table.2 Influence of organic, inorganic nutrients and biofertilizers on Individual Fruit Weight (g) and total fruit yield per hectare (tonnes) of tomato (COTH 3) grown in two seasons

\begin{tabular}{|c|c|c|c|c|c|c|}
\hline \multirow{2}{*}{ Treatments } & \multicolumn{3}{|c|}{ Individual fruit weight $(\mathrm{g})$} & \multicolumn{3}{|c|}{ Fruit yield per hectare (tonnes) } \\
\hline & $1^{\text {st }}$ season crop & $2^{\text {nd }}$ season crop & Pooled mean & $1^{\text {st }}$ season crop & $2^{\text {nd }}$ season crop & Pooled mean \\
\hline $\mathrm{T}_{1}$ & 52.02 & 53.16 & 52.59 & 97.89 & 96.00 & 96.94 \\
\hline $\mathrm{T}_{2}$ & 59.37 & 59.88 & 59.62 & 107.67 & 113.77 & 110.72 \\
\hline $\mathrm{T}_{3}$ & 57.17 & 58.24 & 57.70 & 106.61 & 110.98 & 108.79 \\
\hline $\mathrm{T}_{4}$ & 60.72 & 60.22 & 60.47 & 114.67 & 117.46 & 116.06 \\
\hline $\mathrm{T}_{5}$ & 56.98 & 56.52 & 56.75 & 102.70 & 108.04 & 105.37 \\
\hline $\mathrm{T}_{6}$ & 55.16 & 54.96 & 55.06 & 99.27 & 100.06 & 99.66 \\
\hline $\mathrm{T}_{7}$ & 63.76 & 63.20 & 63.48 & 121.90 & 123.79 & 122.84 \\
\hline $\mathrm{T}_{8}$ & 64.16 & 64.55 & 64.35 & 124.26 & 125.89 & 125.07 \\
\hline $\mathrm{T}_{9}$ & 62.02 & 61.19 & 61.60 & 118.11 & 119.82 & 118.96 \\
\hline $\mathrm{T}_{10}$ & 65.16 & 65.20 & 65.18 & 125.09 & 126.40 & 125.74 \\
\hline SE.d & 0.0702 & 0.0658 & 0.0678 & 0.1686 & 0.1721 & 0.1692 \\
\hline$C D(p=0.05)$ & 0.1474 & 0.1382 & 0.1423 & 0.3542 & 0.3615 & 0.3556 \\
\hline
\end{tabular}


Among the treatments $\mathrm{T}_{10}(50 \% \mathrm{~N}+50 \% \mathrm{P}$ and $100 \% \mathrm{~K}$ of $\mathrm{RDF}+2 \mathrm{~kg}$ Azophosmet) registered the highest fruit yield $(126.40 \mathrm{t}$ ha ${ }^{1}$ ) followed by $\mathrm{T}_{8}(50 \% \mathrm{~N}+50 \% \mathrm{P}$ and 100 $\% \mathrm{~K}$ of RDF $+4 \mathrm{~kg}$ Azophos) which recorded $125.89 \mathrm{t} \mathrm{ha}^{-1}$ but the treatment $\mathrm{T}_{1}$ (control) registered the less yield $\left(96.00 \mathrm{t} \mathrm{ha}^{-1}\right)$. In both the seasons, the treatment $\mathrm{T}_{10}(50 \% \mathrm{~N}+50 \%$ $\mathrm{P}+100 \% \mathrm{~K}$ of RDF $+2 \mathrm{~kg}$ Azophosmet) had highest fruit yield per hectare (125.74 $\left.\mathrm{t} \mathrm{ha}^{-1}\right)$ and the treatment $\mathrm{T}_{1}$ (control) recorded lowest fruit yield per hectare $\left(96.94 \mathrm{t} \mathrm{ha}^{-1}\right)$.

Inorganic nutrients, biofertilizers had a dominant role in increasing fruit weight and yield per unit area. The enhanced photosynthetic activity due to Azospirillum might have favoured an increased accumulation of dry matter and also efficient partitioning of photosynthates towards the sink. Increased yield could be due to properly colonized roots, increased water and mineral uptake from soil and biological nitrogen fixation (Okon, 1985).

It could also be attributed to the production of IAA, and cytokinin like substances produced by the bacterium as evident from the findings of Veeraragavathatham et al., (1988) in chillies, Jeeva Jothi et al., (1993) in cabbage, Subbiah (1993) in tomato, Swaminathan et al., (1993) in amaranthus and Wange (1996) in carrot.

In tomato, the number of fruits per plant and average fruit weight determine the ultimate yield (Thomson and Kelly, 1971). The yield was almost doubled in shade net house during both the seasons as compared to open field condition, this may be due to the enhancement of yield attributing characters viz., plant height, number of branches, fruit circumference, number of fruits per plant and average fruit weight. Ganesan (2004) and Ramesh kumar and Arumugam (2010) also reported similar findings for tomato crop.

\section{References}

Dhanalakshmi, P and C.M. Pappiah. 1993. Effect of Azospirillum inoculation and nitrogen fertilization on growth and yields of Tomato (Lycopersican esculentum Mill) var.PKM-1. Golden Jubilee Symposium-Horticultural Research Changing Scenario, Bangalore, India.

Diokova, M., V. Rankov, G. Dimitrov and Y. Enchava. 1981. Nutrient uptake by plants. Nauchni Trudove, Vissh Selskostopanski Vasil Kolerov 26 (2): 91-97

Ganesan, M and H.D. Subashini. 2001. Study on biometric characteristics of tomato grown in poly green house and open field conditions. Madras Agric. J. 88 (10-12): 682-684.

Gaur. (1990). Phosphate solubilizing microorganisms as biofertilizers. Omega Scientific publishers. New Delhi.

Hammond, L.C., C.A. Black and A.C. Norman. 1951. Nutrient uptake by soyabeans on two JOWA Soils IOWA Agri Expt stn Res. Bul., 384: 463- 512.

Jeeva Jothi, L.A, K. Mani. C.M. Pappiah and R. Raja Gopalan. 1993. Influence of NPK and Azospirillum on the yield of cabbage. South Indian Hort., 41 (5): 270-272.

Karuthamani, S. 1995. Studies on the effect of N, P with Azospirillum and Phosphobacteria on growth, yield and quality of pumpkin $\mathrm{Cv}$. CO2, M Sc. (Hort.) Thesis, TNAU, Coimbatore.

Nandhakumar. S and T. Veeraragavathatham. 2003. Role of integrated nutrient management on the nutrient content of plant tissues in bringal (Solanum melongena) $\mathrm{Cv}$. PLR -1. South Indian Hort.,(1-6):163-167.

Okon, 1985. Azospirilum as a potential inoculants for agriculture. TIBTECH, 3: 
223-228.

Ramesh Kumar. S and T. Arumugam. 2010. Performance of vegetables under naturally ventilated polyhouse condition. Mysore J. Agric, Sci., 44(4): 770-776.

Rokade, S. K and P.L. Patil. 1993. Phosphate solubilizing microorganisms A review 11. J. Maharashtra Agric. Univ., 18 (1): 93- 101

Subbiah, K. 1993. Azospirillum and nitrogen interaction in tomato, Golden Jubilee Symbosium - Horticultural changing scenario, Bangalore, May 24-28, 5(15): 116.

Swaminathan, V. S. Sambandanmoorthi and K. Appavoo. 1993. Effect of Azospirillum on the yield and quality of Amaranthus spp. Golden Jubilee symoposium- Horticultural Research changing scenario, Bangalore, May 24-
18, 1993, abstracts., 5(55): 135.

Thomson, H.S and W.C. Kelley. 1971. Vegetable crops. Fifth edition, $M c$ Graw-hill Book Co.

Veeraragavathatham. D, S. Sundararajan, S. Jayasankar. E. Vadivel and K.G. Shanmugavelu.1988. Effect of nitrogen and phosphorus application and Azospirillum inoculation on Chilli [Capsicum annuum (L.)] National Seminar on Chillies, Turmeric and ginger held at Hyderabad, Jan.11-12: 65-70.

Venkataswarlu, B. and A.V. Rao. 1983. Response of pearl millet to inoculation with different strains Azospirillum brasilense Plant soil, 74: 379- 386.

Wange, S.S. 1996.Effect of biofertilizers under graded $\mathrm{N}$ levels on carrot (Daucus carota L.) Ann. Plant physiol., 10 (1): 96- 98.

\section{How to cite this article:}

Sridharan, S., S. Mariappan and Arumugam, T. 2017. Influence of Organic and Inorganic Nutrients in Tomato (Solanum lycopersicum L.) For Nutrient Uptake and Yield under Shade Net Condition. Int.J.Curr.Microbiol.App.Sci. 6(8): 2904-2908.

doi: https://doi.org/10.20546/ijcmas.2017.608.347 